\title{
KERK EN PERS
}

\section{Dr. W. J. de Klerk}

\section{Kerk en pers}

Ek kan hieroor nie anders praat as vanuit die perspektief van die gebrokenheid nie - 'n baie prominente Geref. leerstuk wat soos 'n stuk leer in die praktyk gehanteer word - dikwels. Dis asof baie nie die volle konsekwensies van gebrokenheid deurdink nie.

Kerk en pers - en gebrokenheid.

Die kerk is die spieël van die sakrale. Die heilige wêreld van die woord, bekering, stryd, geloof en liefde is die beeld wat gekaats word.

En dit is ook die agenda van die kerkinstituut -

Om boosheid teen te staan.

Om geloof te begelei.

Om godsdienstig en sedelike norme te vestig en te bewaar en te bevorder.

Om genade te bedien.
Die pers is die spieël van die profane. Die verkondiger van wat op die gebroke aarde gebeur.

Uitstaller van die verwoestende weg van die sonde soos dit openbaar word in misdaad, bedrog, haat, botsing, skande, geweld, hoer en rumoer.

Die styl vallyn van dié bedorwenheid is die beeld wat die pers kaats.

En sonder genade - 'n oog om oog.

Baie prakties gesien is dit eintlik twee wêrelde - pers en kerk. Nie alleen in die teenstelling sakraal en profaan nie, maar ook verder. Die kerk is die toedekker wat die sondaar spaar en die sonde slaan. Die pers is die oopvlekker wat die sondaar slaan - selfs tot hy nakend staan - pimpel en pers. Die kerk is die draer van baie se geheime in pastorale bewoënheid en die pers is die verklikker. En só kan ons aangaan. Twee wêrelde.

\section{Nie die laaste woord is hierdie stelling nie}

Ons almal staan ook onder die opdrag om die gebrokenheid te bestry, die harmonie te soek en die Woord van God te laat heers ook oor die pers.

Naas die gebrokenheidsperspektief geld die Koninkryksperspektief wat eis dat die pers diensbaar moet wees aan die beginsels van die Bybel.

In die kerk - by sinodes en eredienste - by pastoraat en prediking, is die twee magte aan 't stry: Gebrokenheid versus koninkryk en anders om.

Daar is tye, plekke en geleenthede waar die kerk oorwin met die koninkryk, maar daar is tye, plekke en geleenthede waar die kerk ook maar hangkop staan want die kwaad was sterker en die kerk - as instituut, as vergadering, as enkele gelowige, as dominee - het vasgeval in die gebrokenheid. 
So ook die pers.

Die koninkryk kom ook in die pers. Maar die gebrokenheid loop ook in die pers rond soos 'n brullende leeu. Ons kan dus nie staan en spog teenmekaar nie. In die kerk is daar die struikelblokke vir die koninkryk. En so ook in die pers.

Ek wil 'n paar struikelblokke noem vir die pers in Suid-Afrika - by name Afrikaanse koerante - wat die weg van die Koninkryk in die pers bemoeilik.

Die pers se funksie, sy aard, sy sinskern is 'n riskante onderneming wat hom dwing na die troebelwaters

- As nuusverspreider is sy weiveld die moerasse van die sonde; sy aanknopingspunt is die psigologie van die gevalle mens wat 'n smak het vir die negatiewe, die opsienbarende, die skokkende. Oorlog is groter nuus as vrede; geldverduistering is nuus teenoor goeie geldbestuur wat geen nuus is nie; korrupsie in regering is nuus teenoor normale goeie gang van landsbestuur; moord is nuus dat mense nog lewe is geen nuus nie. Dis ook reg so: nuus is veral waar van die normale, aanvaarde, beplande weg afgewyk word. In die oortreding van die Tien Gebooie lê die werklikheid oop en bloot. En die pers moet dit vertel - dis sy funksie.

- As onthuller is hy gedwing tot die storie agter die storie. Hy moet die waarheid probeer opdiep, die skuldige aanwys, die maskers afpluk - dis sy funksie. Maar om dit reg te kry moet hy snuffelneus wees, spelbederwer, afluisteraar, verklikker. Dis 'n riskante onderneming, gesien vanuit die wette van die koninkryk. Maar dis sy funksie.

- As vermaker moet hy op die bal bly van die wye spektrum van sy nie geselekteerde lesers. Van perde tot nagklubs, van blokkiesraaisels tot bikini-parades, van poporkeste tot filmsterre, is die leefwêreld van sy lesers. Dis 'n riskante onderneming, gesien vanuit die wette van die koninkryk, om vir 20-eeuse gesekulariseerde Afrikaners van alle ouderdomsgroepe, wat roep na moderne vermaak vermaak te gee.

- As gespreksmedium is hy - kragtens sy funksie - ingewerp in die kaleidoskoop van verskillende aksente en standpuntstellings. In sy nuuskolomme praat eksistensialiste, moraliste, nihiliste ens. hetsy deur onderhoud van 'n nuuspersoonlikheid, hetsy deur openbare verklarings, hetsy deur amptelike standpuntstellings. Die goeie, betroubare koerant het kragtens sy funksie nie sensuur oor menings van mense wat in die stroom van die nuus staan nie. Dis 'n risiko om die hele wêreld en sy standpuntstellers op jou preekstoel te laat klim. As 'n koerant dit weier is hy nie meer koerant nie. Dan is hy seksionele lyfblad of orgaan. Maar as hy koerant wil wees, is hy 'n forum. 
- As kommentator is hy blootgestel aan die geweldige tempo van daaglikse standpuntstelling - gelewer binne die bestek van 2-3 uur - oor aktualiteite. Onder die leiding van een man - ook maar verduister in die verstand en begrens deur eie vermoëns, moet die koerant sy beginsel sê sê - elke dag - oor alles en nog wat. Wat 'n risiko - ook vir 'n gelowige. $\mathrm{Om}$ in die openbaar gekonfronteer te word en antwoorde te gee oor dinge wat nie altyd eenvoudig en deursigtig is nie.

- As besigheidsinstelling - want dit is ' $n$ koerant basies - is hy ingestamp in dinge soos kompetisie, vraag en aanbod, populêre smaak, advertensie-aantrekking wat ten minste saamhang met sirkulasie, wins en verlies, ens. Wie in hierdie besigheidsritme beweeg het groot versoekings om die norm van sukses toe te pas en die norm van die koninkryk in 'n lae noot te speel. Dis dié dinge - sy funksie en aard - wat die koerant gedurig stoot - stoot na die grense en wat hom dwing tot projekte en aanbiedinge wat vanuit die Koninkryk gesien, riskant is. Die gebrokenheid is vir hom die wesenlike want hy is rapporteerder, juis van gebrokenheid.

- Die grootste struikelblok vir die koninkryk in die koerantwese in Suid-Afrika is die gebrek aan 'n beduidende deurleefde Christelike maatskappy onder Afrikaners. Ons is min Afrikaners. Swak koerantleser. En blykbaar sterk gesekulariseerd. Want op ons koerante is daar 'n aanslag om laer en laer te daal na die smaakvlak van ons mense. Sirkulasiesyfers bewys die stelling dat "die volk" meer sensasie, goedkoop joernalistiek, duistere dinge, vieslikhede en skandes vra.

Ons Afrikaanse koerante (sommige meer, sommige minder) behoort meer bedank, geprys en geëer te word vir ons weerstand teen die aanvraag. Die probleem is egter dat ons nie alleen vir 'n sekere groep kan skrywe nie. Die Afrikaners is te min. Om te kan voortbestaan moet koerante min of meer die "hele volk" as sy adres hê. Dis 'n duur onderneming. Afgesien van die terrein-afbakening, sal die kerk nooit koerant kan uitgee nie - daarvoor is kerkgeld te veel kleingeld. En selfs waar ons - DT by name - sy lesers wil trek uit 'n meer gesofistikeerde bolaag en middellaag, bly die aanvraag wegbeweeg van die strengste norme van die Koninkryk.

Daar is dus baie struikelblokke vir Afrikanse koerante om die Koninkryk te laat kom in hulle kolomme.

En - al wil jy ook, is die funksie van die koerant 'n riskante besigheid, gesien in koninkrykslig.

Intussen moet ons - ook die koerante - diensbaar wees aan die Koninkryk. Hoe probeer ons dit doen? En nou moet elke redakteur maar vir homself praat. 
- Deur nuus-seleksie. Die Transvaler probeer sover moontlik sekere dinge van die orde van die duisternis weer uit die koerant.

- Deur nuus-plasing. Prominensie word geweer van die dinge wat teen die grein ingaan van die koninkryk.

- Deur nuus-aanbieding. Soberheid, terughoudendheid, goeie smaak word gesoek in die donker dinge.

- Balans, sodat die koerant nie oorwoeker word deur die „vlees wat teen die gees stry nie".

- Ruimte, ook vir die goeie, die Koninkryk se manifestasies in kerk, kultuur, volk en politiek.

- Kommentaar en agtergrond wat poog om vanuit die beginselfundering lig te werp op die aktualiteite.

En nog veel meer.

Natuurlik is daar volop glipse. Hetsy deur verkeerde oordeel, haastige beslissing, interne kortsluitings in die organisasie, personeel wat nie sensitief is vir die koninkryk nie. En ook glipse deur verleiding om tog maar, ter wille van 'n ,schoop" of 'n stoot in sirkulasie, maar oë toe te knyp. Maar opsetlikheid is daar weinig.

1. Die kerklike ampsdraers se verwarrende oordeel oor wat permissief is in die pers

Die pers word rondgeslinger deur kerklike ampsdraers en hulle invloed, tussen: moralisme en subjektiwisme t.o.v. sedelike norme. 'n Lewensvreemde afwysing en saam nie, raak nie, roer nie. 'n Swaarmoedige swartkous konserwatisme. 'n Ontkenning van die realisme van seksualiteit, liggaamlikheid en vrolike jeugdige aktualiteit op die vlak van ontspanning en die eie jeug subkultuur. Die vreemdste definisies van pornografie en dominees oë wat prikkeling sien waar ander nie van onkuise prikkeling droom nie.

'n Baaikostuumfoto van 'n goedgeboude meisietjie.

'n Lenige been wat êrens deur 'n aandrok loer.

'n Lae-hals ronding by 'n filmster.

'n Suggestie van iemand wat ' $n$ vrou bed toe gesleep het.

Al hierdie dinge en nog meer is genoem alledaagse lewensgrepe wat almal aan gewoond is sonder 'n tweede oogopslag. Maar die pers kry slae oor pornografie wat nie pornografie is nie. Oor nuus wat nie mooi is nie. Oor popmusiek-rubrieke en mede-foto's. Die pers moet dié dinge met goeie smakk hanteer en terughouding en eerbied betoon. Maar die kerk en sy ampsdraers moet sedelike norme meer objektief, goed gemotiveerd en ewewigtig hanteer.

\section{Die kerklike-sfeer se oordeel oor die nuusbegrip}

Die nuus is dit wat vir ' $n$ redelike groep mense relevant is. Nuus is rapport van (ook) gebrokenheid. En daarom het alle nuus 'n sensasie-element. Sensasie is wesenselement van nuus-sensasie is die ongewone, skokkende, opwindende van die gebeure. Die verwyt dat koerante op sensasie bou, is om 'n koerant sy nuusfunksie te ontsê. 
Natuurlik kan sensasie oordryf word, kunsmatig opgejaag word of opsetlik geskep word. Ook die koerant moet sober wees. Maar die kerk moet nugter wees - sensasie is 'n deel van nuus.

\section{Die kerk se aanspraak op pers-beskerming}

Die argument in kerklike kringe gaan dikwels so: as die sonde sy doosweg deur die kerk loop, is dit skandalig dat die pers daaraan publisiteit gee. Die kerk kan met reg aanspraak maak op beskerming. Dit gaan om die skade vir die koninkryk as die kerk se beeld in die openbaar geskaad word.

Die argument van die koerant is: sy betroubaarheid hang af van sy eerlike rapport sonder aansiens des persoons. Hy moet nie boeties hê wat hy wegsteek as hulle foutmaak nie. Hy moet probeer om alle mense oor een kam te skeer. Dit is sy „eerlikheidsnorme", as ons dit so kan stel.

Verder - hoe hoër die boom hoe meer die wind. Daarom moet die kerk en sy mense as hoë bome, sorg dat hulle uit die wind bly.

\section{Die kerk se verskraalde nuus-aanbieding}

Koerante soek ook Koninkryksnuus. Maar dan moet dit aangebied word: nuuswaardig, verteerbaar, van algemene belang vir baie lesers. Die kerk moet ook begrip en beheersing hê van die taal van die koerantmedium. Dis nie die koerant se taak om preke te publiseer nie. Of diepgaande teologiese diskoerse nie. Of vae algemeenhede nie. Of alleen negatiewe afkeurings nie - so 'n negatiewe koerant het min oorlewingskans.

Ons ervaar dat 'n dominee soms hopeloos is om kommentaar te vra oor 'n aktuele aangeleentheid: Hy trek los en loop sy rondes teen die sondes in die tale Kanaäns of hy teologiseer so swaar dat alleen die begenadigdes hom sal begryp. Of hy is so 'n sakrale figuur dat hy niks weet van wat om hom gebeur om sinvolle kommentaar te lewer nie. Dieselfde geld kerknuus wat te vaal en algemeen aangebied word. Die koerant sal die kerke baie meer dra as die kerke hulle aanbiedinge reg sny vir koerante.

Wees spesifiek, konkreet, vat een duidelike gedagte, formuleer sterk, prikkelend en eenvoudig, kry 'n spesifieke aktuele invalshoek, haal die nuus uit die ding... En die koerantkolomme sal vir die kerk oopgaan. Vir sy sending en evangelisasie, sy armsorg en pastorale arbeid, sy studie-bevindinge en sy lig op die gebeure van dié dag.

5. Die kerk se politieke oorversigtigheid

Ons Afrikaanse koerante probeer - tot irritasie van sommige deurbreek na die politieke eise van ons tyd en na noodsaaklike en gefundeerde verandering in ons volkeverhoudingsvraagstuk. Ons ervaar te veel in kerklike kringe 'n politieke verkramptheid en wensdinkery wat ons werk probeer aftakel op politieke vlak. Dit bring van die koerant se kant 'n soort ,afkoeling" en onttrekking van 'n kerk en sy vergaderinge wat remmers en stremmers is op die vlak van politieke reoriëntasie. 
Die Afrikaanse koerant is nog nie gesekulariseerd nie, nog nie 'n mag teen die diep vlakke van ons Christelike tradisie nie. Ons koerante is nog oop, sensitief en gewillig om die koninkryk te bevorder, prinsipieel te dink en die prinsipiële te bevorder.

As die kerk...

- Die wese en funksie van die pers begryp en hom nie wil indwing teen sy eie aard in nie.

- Die probleme van die pers begryp in ons Afrikaanse samelewing - die gebrek aan 'n deurleefde Christelike maatskappy, min lesers en besigheidsmededinging.

- Die kommunikasie met die pers opknap na inhoud en vorm.

- Negatiwisme en sektariese preutsheid laat vaar.

- Sy aktualiteitsvisie skerper stel oor die hele linie van ons samelewing.

... Dan sal kerk en pers 'n nuwe binding vind.

As die pers...

- Sy verantwoordelikheid dieper beoefen.

- Sy terughoudendheid teenoor die onsmaaklike sterker toepas.

- Sy verbintenis met die Christelike beginsels opsetliker en openliker uitstraal.

... Dan sal die pers 'n bondgenoot word van die dinge wat die kerk dierbaar ag.

Ons moet wedersyds ons gebrokenheid help dra.

En ons Koninkryksroeping wedersyds help bevorder.

(Gelewer voor die Jaarlikse Saamtrek van die G.T.V. te Pretoria, 10 Junie 1975.) 